\title{
Tanggung Jawab Notaris Terhadap Akta Jual Beli Saham Dengan Surat Kuasa Mewakili Yang Tanggalnya Melampui Akta
}

\author{
Anak Agung Ayu Adinda Putri'1,I Gusti Ayu Putri Kartika² \\ 1Fakultas Hukum Universitas Udayana,Email: ayuadinda0395@gmail.com \\ ${ }^{2}$ Fakultas Hukum Universitas Udayana, Email: akartika09@yahoo
}

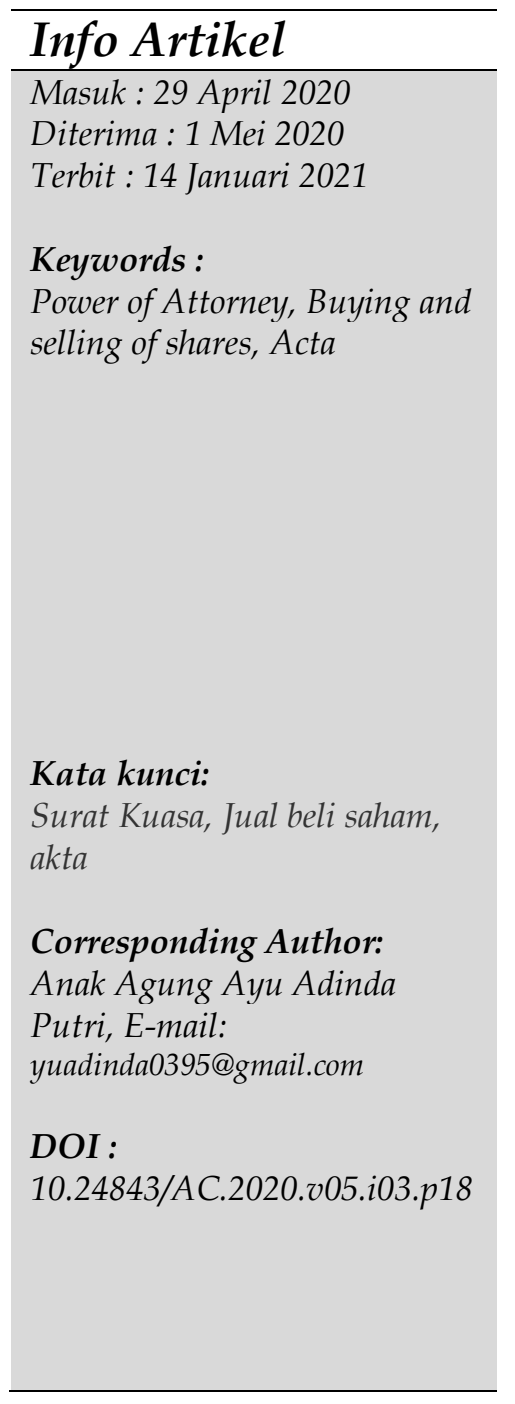

\begin{abstract}
A share sale and purchase deed made by a notary based on a power of attorney whose date exceeds the deed often results in legal consequences. To determine the legal consequences that arise, Normative research is used, a statutory approach, uses primary and secondary legal material sources, and uses document study techniques. The aim is to be able to discuss the problems that arise, namely what are the legal consequences arising from the sale and purchase of shares by a notary based on a power of attorney representing the date beyond the deed and what is the form of responsibility by the notary from the legal consequences arising from the making of a share sale and purchase deed based on a power of attorney represents whose date exceeds the deed. The conclusion is that the authentic form of the deed has lost its authenticity, the authority of the party in the deed is considered invalid and invalid.

\begin{tabular}{l}
\hline Abstrak \\
\hline Akta jual beli saham yang dibuat oleh Notaris berdasarkan surat \\
kuasa yang tanggalnya melampui akta seringkali menimbulkan \\
akibat hukum. Penelitian ini menggunakan jenis penelitian \\
Normatif, pendekatan undang-undang, menggunakan sumber \\
bahan hukum primer dan sekunder, dan menggunakan teknik \\
studi dokumen. Tujuannya adalah untuk mengetahui akibat \\
hukum yang timbul dari akta jual beli saham oleh Notaris \\
berdasarkan surat kuasa mewakili yang tanggalnya melampaui \\
akta dan untuk mengetahui bentuk tanggung jawab oleh Notaris \\
dari akibat hukum yang timbul karena pembuatan akta jual beli \\
saham berdasarkan surat kuasa mewakili yang tanggalnya \\
melampui akta. Kesimpulannya adalah bentuk akta otentik \\
tersebut hilang otentisitasnya, kewenangan dari penghadap di \\
dalam akta dianggap tidak sah dan tidak berlaku.
\end{tabular}
\end{abstract}

\section{Pendahuluan}

Pengangkatan Notaris oleh pemerintah adalah untuk menjalani tugas melayani masyarakat dan memiliki kewenangan secara atributif dari Negara untuk memberikan pelayanan dalam hubungan hukum yang terjadi serta dapat digunakan sebagai alat bukti oleh mereka dengan menggunakan dokumen legal yang sah dan memiliki 
kekuatan hukum serta pembuktian yang sempurna, dalam tindakannya tersebut Notaris berpedoman pada Peraturan Jabatan Notaris dan Kode Etik Profesi Notaris. ${ }^{1}$

Menjalankan fungsi publik dari Negara didalam bidang hukum privat adalah merupakan tugas dari Notaris yang perannya membuat akta otentik dengan kekuatan pembuktian yang sempurna. Notaris terikat dengan ketentuan yang diatur di dalam UUJN sehingga memperoleh kepercayaan berdasarkan kode etik Notaris yang dijalankan. Kode Etik Notaris adalah kaidah moral yang ditentukan oleh Ikatan Notaris Indonesia berdasarkan Keputusan Kongres Perkumpulan dan/atau yang ditentukan dan diatur dalam peraturan perundang-undangan yang mengatur tentang hal itu dan yang berlaku bagi serta wajib ditaati oleh setiap dan semua anggota perkumpulan dan semua orang yang menjalankan tugas dan jabatan sebagai Notaris. ${ }^{2}$

Akta Otentik sebagai alat butki yang sempurna, maka tidak akan dibutuhkan lagi buktibukti penunjang lainnya, dan akta otentik dianggap benar karena dibuat oleh dan dihadapan pejabat umum yang berwenang. Akta yang dibuat Notaris di Indonesia memiliki kekuatan bukti formil, materiil, dan untuk perbuatan hukum tertentu juga mempunyai kekuatan eksekutorial. ${ }^{3}$

Berbagai macam transaksi yang dilakukan oleh manusia sebagai masyarakat pekerja didalam suatu perusahaan adalah transaksi melakukan jual beli saham, terhadap saham-saham yang telah dimiliki oleh masing-masing persero mempunyai hak dan keinginan masing-masing persero untuk menjualnya. Jual beli saham didalam suatu perusahaan dilakukan berdasarkan keputusan Rapat Umum Pemegang Saham (RUPS) yang sebelumnya telah diadakan rapat oleh para pemegang saham, yakni oleh Direktur, Komisaris dan persero lainnya yang telah menyetorkan sahamnya ke dalam perseroan.

Alat bukti yang digunakan oleh masyarakat dulu hanyalah alat bukti saksi yang telah menyaksikan sedang berlangsungnya transaksi mereka, namun meningkatnya populasi manusia dalam tahun ke tahun menyebabkan terjalinnya hubungan manusia yang semakin kompleks, dan alat bukti berupa saksi pun dianggap kurang memastikan, maka dalam kelemahan ini diciptakanlah alat bukti tertulis. ${ }^{4}$

Jual beli saham yang dilakukan oleh persero perusahaan membutuhkan alat bukti tertulis sehingga dikemudian hari dapat menjamin kepastian hukum, kapan dan dimana jual beli saham tersebut dilakukan, jual beli saham ini harus dilakukan di hadapan pejabat yang berwenang. Alat bukti tertulis dapat dikeluarkan oleh pejabat yang berwenang, salah satunya adalah Notaris, Notaris adalah pejabat yang berwenang untuk membuat akta otentik dengan menjamin kepastian hari, tanggal dan waktu kapan

${ }^{1}$ Angelina, L. (2019). Tanggung Jawab Notaris Dalam Akta Jual Beli Dan Pengalihan Hak Atas Saham Yang Dibuat Dengan Tanggal Mundur (Back-Dated). Indonesian Notary, 1(001). hal. 22.

${ }^{2} E d w a r d$, N. (2012). Pemberian Kuasa Menjual Dalam Transaksi Jual Beli Saham Pengendali Bank (The Granting of a Power of Attorney to Sell in a Sale and Purchase of the Controlling Shares of a Bank). Available at SSRN 3095838. hal. 15

${ }^{3}$ Pertiwi, E. (2019). Tanggung Jawab Notaris Akibat Pembuatan Akta Nominee Yang Mengandung Perbuatan Melawan Hukum Oleh Para Pihak. Jurnal Rechten: Riset Hukum dan Hak Asasi Manusia, 1, 41-55. hal. 45.

${ }^{4}$ Lumban Tobing, G. H. S. (1999). Peraturan Jabatan Notaris. Cetakan Kelima, Gelora Aksara Pratama, Jakarta. hal 30. 
dibuat akta tersebut. ${ }^{5}$

Tindakan jual beli saham oleh persero perusahaan akan dituangkan ke dalam akta jual beli saham oleh Notaris, namun pada saat dilakukannya jual beli saham di kantor Notaris pada kesempatan itu juga pihak-pihak yang melakukan jual beli saham salah satunya karena kondisi atau situasi yang mendesak berhalangan hadir di hadapan Notaris, maka dibutuhkanlah Surat Kuasa untuk memberikan kuasa terhadap orang yang dikuasakan untuk melakukan tindakan hukum yang diperlukan di hadapan Notaris. Surat Kuasa merupakan surat yang menunjuk kepada orang yang dikuasakan khusus untuk melakukan tindakan hukum yang diperlukan sesuai dengan pemberian kuasa dalam hal ditulis di dalam Surat Kuasa. ${ }^{6}$

Macam-macam Surat Kuasa adalah ada yang berbentuk di bawah tangan dan ada juga yang berbentuk Notariil atau akta, Surat Kuasa di bawah tangan dalam bentuknya adalah diperlukan legalisasi oleh Notaris untuk dapat dipergunakan dan dimasukkan ke dalam komparisi akta, sedangkan Surat Kuasa dalam bentuk akta atau Notariil adalah bersifat otentik tetap juga dapat dipergunakan dan dimasukkan ke dalam komparisi akta. Pemberian Surat Kuasa biasanya kepada orang yang dikuasakan adalah sesama persero, dan saudara si pemberi kuasa. ${ }^{7}$

Surat kuasa yang seringkali digunakan untuk mewakili seseorang dalam berbuat hukum adalah surat kuasa di bawah tangan. Surat kuasa di bawah tangan memiliki kelemahan yakni dalam hal pembuktian. Pembuktian surat kuasa di bawah tangan tidaklah sama dengan pembuktian surat kuasa otentik. ${ }^{8}$ Permasalahan yang sering ditemukan di dalam akta jual beli saham yang salah satu pihaknya diwakilkan dengan menggunakan surat kuasa di bawah tangan, namun tanggal surat kuasa tersebut melewati atau melampaui tanggal akta jual beli saham, biasanya hal seperti itu adalah kecerobohan yang dilakukan oleh Notaris karena tidak melakukan pekerjaannya dengan teliti membaca tanggal Surat Kuasa dengan tanggal akta jual beli saham, berdasarkan pasal yang tertera di dalam UUJN telah mengatur mengenai bentuk akta otentik, sehingga dalam permasalahan di atas dapat dikatakan akta jual beli saham tersebut kehilangan otentisitasnya.

Berdasarkan latar belakang diatas bahwa tanggal surat kuasa yang telah melampui akta dianggap tidak sah dan batal demi hukum, karena seharusnya tanggal surat kuasa mewakili untuk menandatangani akta haruslah tanggalnya sebelum akta yang akan dibacakan. Tujuan penelitian ini untuk dapat membahas permasalahan yakni apa akibat

${ }^{5}$ Cakra, D. H. (2019). Keabsahan Pelaksanaan Pemindahan Hak Atas Saham Dalam Perseroan Terbatas (Tertutup) Berdasarkan Undang-Undang No. 40 Tahun 2007 Tentang Perseroan Terbatas. Indonesian Notary, 1(001). hal. 12.

${ }^{6}$ Tedjosaputro, L. (2019). Kajian Hukum Pemberian Kuasa Sebagai Perbuatan Hukum Sepihak Dalam Surat Kuasa Membebankan Hak Tanggungan. Jurnal SPEKTRUM HUKUM, 13(2), 162180. hal 165.

${ }^{7}$ Apriani, F. (2015). Kekuatan Surat Kuasa Dalam Transaksi Jual Beli Barang Menurut Buku II Kitab Undang-Undang Hukum Perdata (Doctoral dissertation, Universitas Muhammadiyah Palembang). hal 21.

${ }^{8}$ Gunari, W. J. (2020). Pembuatan Surat Kuasa Substitusi untuk Menjual Tanah dan Stasiun Pengisian Bahan Bakar Umum (Studi Putusan Pengadilan Tinggi Medan Nomor 199 Tanggal 14 Agustus 2018). Indonesian Notary, 1(004). hal 4. 
hukum yang timbul dari akta jual beli saham oleh Notaris berdasarkan surat kuasa mewakili yang tanggalnya melampaui akta dan bagaimana bentuk tanggung jawab oleh Notaris dari akibat hukum yang timbul karena pembuatan akta jual beli saham berdasarkan surat kuasa mewakili yang tanggalnya melampui akta.

Sebelumnya terdapat penelitian yang berjudul "Pembuatan Surat Kuasa Substitusi untuk Menjual Tanah dan Stasiun Pengisian Bahan Bakar Umum (Studi Putusan Pengadilan Tinggi Medan Nomor 199 Tanggal 14 Agustus 2018)" karangan Gunari, W. J yang membahas mengenai surat kuasa di bawah tangan beserta fungsinya9 dan penelitian yang berjudul "Kekuatan Surat Kuasa Dalam Transaksi Jual Beli Barang Menurut Buku II Kitab Undang-Undang Hukum Perdata" karangan Apriani, F yang membahas macam-macam surat kuasa. ${ }^{10}$

Kedua penelitian sebelumnya berbeda dengan penelitian ini, dimana perbedaannya terletak pada fokus pembahasan yaitu tanggung jawab Notaris terhadap akta jual beli saham dengan surat kuasa mewakili yang tanggalnya melampui akta.

\section{Metode Penelitian}

Jenis penelitian yang digunakan dalam jurnal ini menggunakan jenis penelitian hukum normatif11, menggunakan pendekatan undang-undang, sumber bahan hukum primer dan sekunder, serta teknik studi dokumen, pendekatan undang-undang dilakukan agar mengetahui apakah pasal yang dimaksud tersebut benar-benar telah mengenai isi dari permasalahan yang diangkat, sehingga bisa dilakukan pembahasan yang tepat dan jelas.

\section{Hasil Dan Pembahasan}

3.1. Akibat Hukum yang Timbul dari Akta Jual beli Saham oleh Notaris Berdasarkan Surat Kuasa Mewakili yang Tanggalnya Melampaui Akta

Akta jual beli saham diterbitkan oleh Notaris dikarenakan ada permintaan dari hasil keputusan rapat umum pemegang saham mengenai agenda rapat yang menyatakan jual beli saham, jual beli saham yang dilakukan oleh salah satu pemegang saham perseroan terhadap salah seorang pemegang saham lainnya di dalam suatu perseroan. Permintaan atas dasar hasil keputusan rapat tersebut yang menjadikan dasar Notaris untuk menerbitkan akta jual beli saham, namun dalam situasi dan keadaan yang tidak memungkinkan dari salah satu pihak yang harus hadir berhalangan hadir di hadapan Notaris, hal ini menyebabkan diperlukannya Surat Kuasa mewakili penghadap yang tidak hadir tersebut untuk diwakili kehadirannya di hadapan Notaris. ${ }^{12}$

Surat Kuasa adalah surat yang berisi penunjukan kuasa dari pemberi kuasa terhadap penerima kuasa yang khususnya untuk dapat menjalankan dan melaksanakan

\footnotetext{
${ }^{9}$ Ibid.

${ }^{10}$ Apriani, F, Op.cit.

${ }^{11}$ Koentjoro, N. (2005). Metode-metode penelitian Masyarakat. Jakarta: PT Gramedia Pustaka Utama. hal 22.

${ }^{12}$ Sofyan, S. L. (2010). Analisis yuridis mengenai transaksi jual beli saham dengan hak membeli kembali (repo) dengan menggunakan saham yang diperdagangkan di bursa efek Indonesia (Doctoral dissertation, Universitas Indonesia. Fakultas Hukum). hal. 15
} 
perbuatan hukum dalam hal kepentingan si pemberi kuasa untuk menandatangani sesuatu akta atau surat dan membayar berapa saja yang diperlukan untuk hal tersebut. 13 Surat Kuasa yang diperlukan ada 2 macam yakni Surat Kuasa Notariil dan Surat Kuasa di bawah tangan yang dilegalisasi oleh Notaris dengan berisikan tanggal dan nomor. Tanggal yang menerangkan hari ditandatanganinya Surat Kuasa tersebut haruslah sebelum tanggal akta yang akan ditandatangani oleh penghadap yang hadir berdasarkan Surat Kuasa. ${ }^{14}$

UU Perseroan Terbatas dalam Pasal 56 ayat (3) terjadinya pemindahan saham wajib dicatat oleh Direksi di dalam daftar pemegang saham yang berisikan hari dan tanggal pemindahan hak tersebut, kemudian dari sini terjadinya perubahan susunan pemegang saham yang wajib diinformasikan selambat-lambatnya 30 hari dan informasi ini digunakan akan diterbitkan Surat Keputusan Perubahan Dasta Perseroan oleh Kementerian Hukum dan Ham RI.

Permasalahan terjadi apabila Notaris tidak berhati-hati dalam meneliti dan melegalisasi Surat Kuasa dan memasukkan tanggal dan nomor legalisasi ke dalam komparisi akta jual beli saham, karena dalam penjualan saham perseroan adalah berat hukumnya dalam anggaran dasar perseroan jika penjualan tersebut terlaksana dalam akta jual beli saham yang salah komparisinya yaitu tanggal Surat Kuasa telah melampaui tanggal akta jual beli saham.

Akibat hukum yang timbul akibat dari akta jual beli saham atas dasar Surat Kuasa yang tanggalnya melampaui akta adalah terhadap bentuk akta otentik tersebut berakibat hilangnya otentisitasnya dan kekuatan hukumnya sama dengan akta di bawah tangan, dan kewenangan dari penghadap di dalam akta adalah berdasarkan Surat Kuasa yang tanggalnya melampaui akta telah dianggap tidak sah dan tidak berlaku, sehingga kecakapan hukum penerima kuasa untuk mewakili si penerima kuasa tidak cakap hukum, serta dalam ketidakcapakapan penghadap di dalam akta, maka akta akan kehilangan otentisitasnya.

Kewenangan penghadap yang bertindak berdasarkan Surat Kuasa biasanya dapat dibuktikan dengan melihat Surat Kuasanya dan agar terciptanya kepastian hukum maka Surat Kuasa tersebut dilegalisasi oleh pejabat yang berwenang yakni Notaris. ${ }^{15}$ Tidak berwenangnya para penhadap merupakan tidak cakapnya penghadap dalam melakukan perbuatan hukum, yang dalam hal ini penghadap tidak memenuhi syarat yang telah diatur di dalam UU, dalam Pasal 41 UUJN dengan tegas menentukan apabila terjadi pelanggaran terhadap pembuatan alta otentik maka akan berakibat akta Notaris tersebut kehilangan otentisitasnya.

${ }^{13}$ Widjaja, H. S. (2008). Kajian Hukum Terhadap Surat Kuasa Membebankan Hak Tanggungan (SKMHT) Yang Termuat Dalam Pasal 15 Ayat (1) Undang-Undang Nomor 4 Tahun 1996 Tentang Hak Tanggungan (Doctoral dissertation, Program Pascasarjana Universitas Diponegoro). hal 32.

${ }^{14}$ Prasminda, G. D., Usfunan, Y., \& Udiana, I. M. (2017). Kuasa Menjual Notariil Sebagai Instrumen Pemenuhan Kewajiban Debitur Yang Wanprestasi Dalam Perjanjian Utang Piutang. Acta Comitas, 2, 57-65. hal 60.

${ }^{15}$ Mongdong, S. V. (2017). Eksistensi Surat Kuasa Terhadap Peralihan Hak Atas Tanah Ditinjau Dari Kuhperdata. Lex Privatum, 5(5). hal 32. 
Terjadinya hal tersebut, adanya pelanggaran yang dilakukan oleh Notaris yakni terhadap aturan Kode Etik Notaris yang terbentuk berdasarkan Pasal 13 Perubahan Anggaran Dasar Ikatan Notaris Indonesia Kongres Luar Biasa Ikatan Notaris Indonesia, dan Pasal 1869 KUHperdata yaitu yang menentukan "suatu akta yang tidak diperlakukan sebagai akta otentik, baik tidak berwenang atau tidak cakap seorang pejabat umum dan ataupun bentuknya mengalami cacat, namun mempunyai kekuatan sebagai tulisan dibawah tangan yang ditandatangani para pihak". Artinya bahwa, apabila adanya kondisi yang disebabkan oleh pelanggaran baik oleh Notaris maupun para pihak, mengakibatkan akta tersebut kehilangan otentisitasnya. ${ }^{16}$

3.2. Bentuk Tanggung Jawab yang Diberikan oleh Notaris dari Akibat Hukum yang Timbul karena Pembuatan Akta Jual Beli Saham Berdasarkan Surat Kuasa Mewakili yang Tanggalnya Melampaui Akta

Kebenaran formil dari akta adalah tanggung jawab dari Notaris, tetapi Notaris juga dapat bertanggung jawab atas kebenaran materiil apabila Notaris dapat membuktikan kebenarannya akan kelalaian atau sengaja sehingga dapat menyebabkan kerugian bagi para pihak, dalam kebenaran materiil, tanggung jawab Notaris dibagi menjadi : ${ }^{17}$

1. Tanggung jawab Notaris dalam bentuk perdata akan kebenaran materiil terhadap akta yang dibuatnya;

2. Tanggung jawab Notaris dalam bentuk pidana akan kebenaran materiil terhadap akta yang dibuatnya;

3. Tanggung jawab Notaris berdasarkan UUJN akan kebenaran materiil terhadap akta yang dibuatnya;

4. Tanggung jawab Notaris berdasarkan Kode Etik Notaris;

Adanya kewenangan dan kewajiban yang dimiliki oleh Notaris, maka lahirlah suatu tanggung jawab terhadapnya, namun tanggung jawan Notaris juga timbul dari adanya pelanggaran atas kelalaian dan kesengajaan yang dilakukan oleh Notaris tehadap akta yang dibuatnya, dalam hal ini dalam akta jual beli saham yang diakibatkan oleh kesalahan dan kelalaian Notaris dalam membuat akta dengan memasukkan ke dalam komparisi akta mengenai tanggal dari Surat Kuasa yang melampaui tanggal akta, akibatnya mengakibatkan kerugian yang besar bagi pihak yang berkepentingan di dalam akta.

Notaris atas perintah UUJN dan Kode Etik dihendaki agar dalam menjalankan tugasnya haruslah tunduk terhadap perintahnya, serta memberikan tanggung jawab terhadap masyarakat yang memakai jasanya, organisasi profesi (INI) atau terhadap Negara, maka terjadinya segala kekacauan serta kekeliruan yang dampaknya menyebabkan kerugian maka Notaris dapat dimintakan tanggung jawab berupa ganti

16 Malik, A. (2010). Pengantar Bisnis Jasa Pelaksana Konstruksi. Penerbit Andi. hal 44.

${ }^{17}$ Anshori, A. G. (2009). Lembaga kenotariatan Indonesia: perspektif hukum dan etika. UII Press. hal 35 
kerugian, pertanggung jawaban atas salahnya dalam membuat akta otentik saat sedang menjalankan jabatannya. ${ }^{18}$

\section{Kesimpulan}

Akibat hukum terhadap akta jual beli saham atas dasar surat kuasa yang tanggalnya melampaui akta adalah hilangnya otentisitas dari akta jual beli saham tersebut dan kekuatan hukumnya sama dengan akta di bawah tangan dan kewenangan dari penghadap di dalam akta adalah berdasarkan surat kuasa yang tanggalnya melampaui akta adalah dianggap tidak sah dan tidak berlaku. Saran yang dapat diberikan adalah pembuatan akta jual beli saham yang penandatanganan pemegang saham diwakilkan berdasarkan surat kuasa haruslah melampui tanggal pembuatan surat kuasa, sehingga akta jual beli saham tersebut tidak hilang kekuatan hukumnya.

\section{Daftar Pustaka / Daftar Referensi}

\section{$\underline{\text { Buku }}$}

Anshori, A. G. (2009). Lembaga kenotariatan Indonesia: perspektif hukum dan etika. UII Press.

Lumban Tobing, G. H. S. (1999). Peraturan Jabatan Notaris. Cetakan Kelima, Gelora Aksara Pratama, Jakarta.

Koentjoro, N. (2005). Metode-metode penelitian Masyarakat. Jakarta: PT Gramedia Pustaka Utama.

Malik, A. (2010). Pengantar Bisnis Jasa Pelaksana Konstruksi. Penerbit Andi.

\section{Jurnal}

Angelina, L. (2019). Tanggung Jawab Notaris Dalam Akta Jual Beli Dan Pengalihan Hak Atas Saham Yang Dibuat Dengan Tanggal Mundur (Back-Dated). Indonesian Notary, 1(001).

Cakra, D. H. (2019). Keabsahan Pelaksanaan Pemindahan Hak Atas Saham Dalam Perseroan Terbatas (Tertutup) Berdasarkan Undang-Undang No. 40 Tahun 2007 Tentang Perseroan Terbatas. Indonesian Notary, 1(001).

Edward, N. (2012). Pemberian Kuasa Menjual Dalam Transaksi Jual Beli Saham Pengendali Bank (The Granting of a Power of Attorney to Sell in a Sale and Purchase of the Controlling Shares of a Bank). Available at SSRN 3095838.

Gunari, W. J. (2020). Pembuatan Surat Kuasa Substitusi untuk Menjual Tanah dan Stasiun Pengisian Bahan Bakar Umum (Studi Putusan Pengadilan Tinggi Medan Nomor 199 Tanggal 14 Agustus 2018). Indonesian Notary, 1(004).

${ }^{18}$ Murniaty, E. (2010). Tanggung Jawab Notaris dalam hal terjadi Pelanggaran Kode Etik (Doctoral dissertation, UNIVERSITAS DIPONEGORO). hal 22. 
Mongdong, S. V. (2017). Eksistensi Surat Kuasa Terhadap Peralihan Hak Atas Tanah Ditinjau Dari Kuhperdata. Lex Privatum, 5(5).

Prasminda, G. D., Usfunan, Y., \& Udiana, I. M. (2017). Kuasa Menjual Notariil Sebagai Instrumen Pemenuhan Kewajiban Debitur Yang Wanprestasi Dalam Perjanjian Utang Piutang. Acta Comitas, 2, 57-65. hal 60.

Pertiwi, E. (2019). Tanggung Jawab Notaris Akibat Pembuatan Akta Nominee Yang Mengandung Perbuatan Melawan Hukum Oleh Para Pihak. Jurnal Rechten: Riset Hukum dan Hak Asasi Manusia, 1, 41-55.

Tedjosaputro, L. (2019). Kajian Hukum Pemberian Kuasa Sebagai Perbuatan Hukum Sepihak Dalam Surat Kuasa Membebankan Hak Tanggungan. Jurnal SPEKTRUM HUKUM, 13(2), 162-180.

\section{$\underline{\text { Tesis atau Disertasi }}$}

Apriani, F. (2015). Kekuatan Surat Kuasa Dalam Transaksi Jual Beli Barang Menurut Buku II Kitab Undang-Undang Hukum Perdata (Doctoral dissertation, Universitas Muhammadiyah Palembang).

Murniaty, E. (2010). Tanggung Jawab Notaris dalam hal terjadi Pelanggaran Kode Etik (Doctoral dissertation, UNIVERSITAS DIPONEGORO).

Sofyan, S. L. (2010). Analisis yuridis mengenai transaksi jual beli saham dengan hak membeli kembali (repo) dengan menggunakan saham yang diperdagangkan di bursa efek Indonesia (Doctoral dissertation, Universitas Indonesia. Fakultas Hukum).

Widjaja, H. S. (2008). Kajian Hukum Terhadap Surat Kuasa Membebankan Hak Tanggungan (SKMHT) Yang Termuat Dalam Pasal 15 Ayat (1) Undang-Undang Nomor 4 Tahun 1996 Tentang Hak Tanggungan (Doctoral dissertation, Program Pascasarjana Universitas Diponegoro).

\section{Peraturan Perundang-Undangan}

Kitab Undang-Undang Hukum Perdata (burgerlijk wetboek), dengan tambahan undang-undang pokok agrarian dan undang-undang perkawinan, diterjemahkan oleh R.Subekti dan R. Tjitrosudibio, 2008, Cetakan 39, Pradnya Paramita.

Undang-Undang Negara RI, Undang-Undang No. 2 Th. 2014 tentang perubahan Undang-Undang Negara RI, Undang-Undang No. 30 Th. 2004 tentang Jabatan Notaris (Lembaran Negara RI Th. 2014 No. 3 perubahan atas Lembaran Negara RI Th. 2004 No. 117 Tambahan Lembaran Negara 4432)

Undang-Undang Negara RI, Undang-Undang No. 40 Th. 2007 tentang Perseroan Terbatas (Lembaran Negara RI Th. 2007 No. 106 Tambahan Lembaran Negara RI No. 4756) 